\title{
On the responsiveness of hardened UF-resins of different molar ratio towards ammonia fumigation
}

\author{
E. Roffael
}

Received: 30 March 2011 / Published online: 20 July 2011

(C) The Author(s) 2011. This article is published with open access at Springerlink.com

\begin{abstract}
Fumigation of two cross-linked UF-resins of molar ratio $\mathrm{U}: \mathrm{F} 1: 2.1$ and $1: 1.4$ with ammonia reduces their formaldehyde release. The reduction seems to be more excessive in case of resin with molar ratio U:F 1:2.1. Ammonia fumigation also increases the nitrogen content of the hardened resins depending on their molar ratio U:F. Resin of the molar ratio $\mathrm{U}: \mathrm{F} 1: 2.1$ is more receptive to ammonia than that of $\mathrm{U}: \mathrm{F}$ 1:1.4. Moreover, the $\mathrm{pH}$-value of aqueous extractives of the resins increases due to the ammonia treatment depending on the molar ratio $\mathrm{U}: \mathrm{F}$ of the resin. Resins with high formaldehyde content are more responsive to ammonia fumigation.
\end{abstract}

\section{Über die Reagibilität von vernetzten UF-Harzen verschiedenen Molverhältnisses auf die Ammoniakbegasung}

\section{Introduction}

Adhesives based on aminoplastic resins, especially urea formaldehyde resins (UF-resins), are used worldwide in the manufacture of various wood-based panels. This is due to the reasonable cost of the UF-adhesives and their fast curing during pressing which allows the use of short press cycles. However, formaldehyde release from wood-based panels bonded with aminoplastic resins became and still is an essential issue of major concern owing to the toxicological importance of formaldehyde; the discussion on that subject is still ferocious and far from being over. Consequently, different techniques have been proposed over the

E. Roffael ( $\varangle)$

Georg-August-Universität Göttingen, Göttingen, Deutschland

e-mail: eroffae1@gwdg.de last decades to abate formaldehyde emission from woodbased panels containing formaldehyde (Roffael 1993). Posttreatment with ammonia and other formaldehyde reactive chemicals as formaldehyde scavengers is one of the methods proposed in the literature to decrease the formaldehyde release (DE-OS 2804514, Westling 1983) emitted from particle- and fiberboards bonded with UF- and MUF-resins. Post-treatment has acquired in many countries industrial application. Other concepts for reducing formaldehyde release have also made headway and bigger inroads into the industry.

Despite a spate of publications dealing with the after treatment of particle- and fiberboards, no systematic work has been devoted to the responsiveness of UF-resins to ammonia fumigation. This paper intends, therefore, to examine the influence of ammonia fumigation on the formaldehyde release of hardened UF-resins of different molar ratios to assess their amenability towards ammonia fumigation.

\section{Experimental work}

For this purpose two resins with the molar ratio (U:F 1:1.4 and 1:2.1) were hardened under exactly the same conditions using ammonium sulfate $(2.4 \%$ based on dry solids) at $120^{\circ} \mathrm{C}$ for two hours. Thereafter the resins were fumigated with ammonia in a desiccator by putting them in a watch glass over ammonium carbonate as a source of ammonia. The formaldehyde release of two cross-linked UF-resins (molar ratio U:F 1:2.1 and 1:1.4) before and after fumigation with ammonia for one week was measured at different time intervals using the flask method following the principle of EN 717-3. 
Table 1 Influence of ammonia fumigation on the $\mathrm{pH}$-value, nitrogen content and formaldehyde release from two cross-linked urea formaldehyde resins of molar ratio U:F 1:2.1 and 1:1.4, the free formaldehyde content of the cross-linked resins is also included

Tab. 1 Einfluss der Ammoniakbegasung auf den pH-Wert, den Stickstoffgehalt und die Formaldehydabgabe von zwei vernetzten Harnstoffformaldehydharzen des Molverhältnisses U:F 1:2,1 und 1:1,4. Der freie Formaldehydgehalt in den vernetzten Harzen ist ebenfalls angegeben

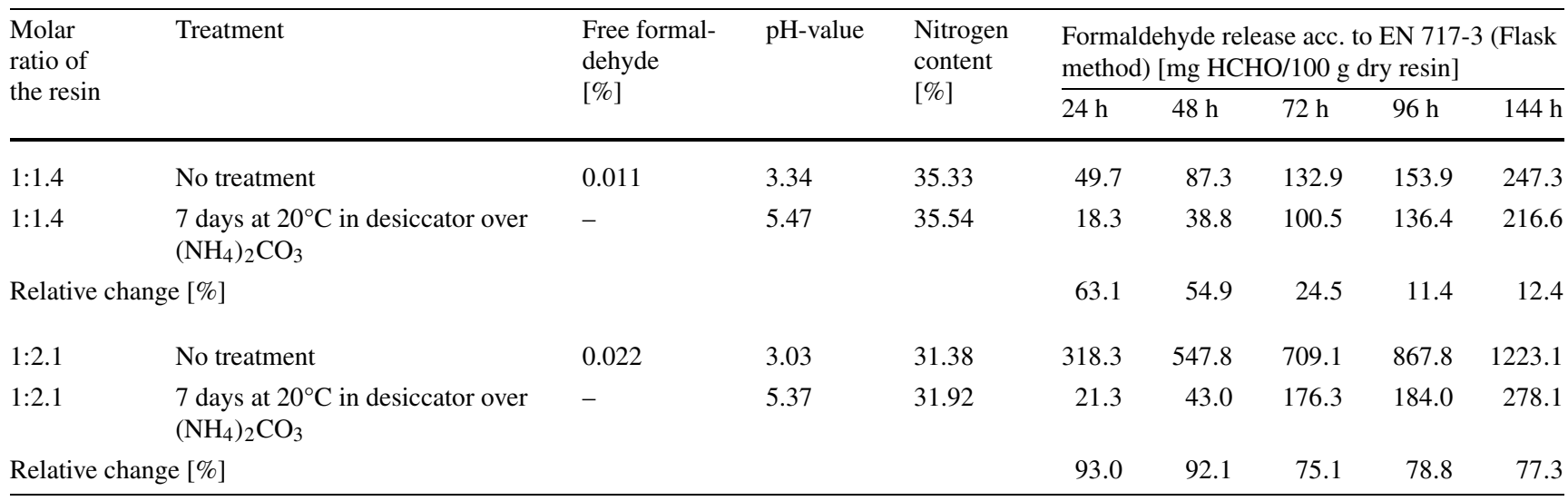

\section{Results and discussion}

The results in Table 1 reveal that in case of the resin with the molar ratio $(\mathrm{U}: \mathrm{F}=1: 2.1)$ the reduction of the formaldehyde release is much more pronounced than in case of the molar ratio resin $(\mathrm{U}: \mathrm{F}=1: 1.4)$. Moreover, it can be inferred from the results that the relative change in the formaldehyde release due to ammonia fumigation decreases with extending the reaction time. This may be due to the liberation of preeminently free formaldehyde and loosely bonded formaldehyde, as methylol groups, in the first stage of testing using the flask method, whereas in the later stages of testing hydrolysis of the cross-linked resin starts to take hold leading to release of formaldehyde, which was originally either not or less accessible to the reaction with ammonia. However this has to be confirmed by in-depth research which is beyond the scope of this paper.

In further experiments, the hardened resins were extracted with water prior to and after fumigation with ammonia. It becomes obvious from the results that due to ammonia exposure the $\mathrm{pH}$-value of the extractives from the hardened resins in water increased drastically from 3.03 to 5.37 in case of the resin with the molar ratio $(\mathrm{U}: \mathrm{F}=1: 2.1)$ and from 3.34 to 5.47 in case of the resin with the molar ratio $(\mathrm{U}: \mathrm{F}=1: 1.4)$.

Ammonia treatment also affects to various degrees the nitrogen content of the cross-linked resins. The nitrogen con- tent of the resin with the molar ratio (U:F $=1: 2.1)$ increased by $0.54 \%$ from $31.38 \%$ to $31.92 \%$, in case of the resin with the molar ratio $(\mathrm{U}: \mathrm{F}=1: 1.4)$ the nitrogen content ascended by only $0.21 \%$ from $35.33 \%$ to $35.54 \%$ indicating that the molar ratio influences the reactivity of cross-linked resins towards ammonia. Furthermore, as the results plainly uncover, the cross-linked resin of the molar ratio $\mathrm{U}: \mathrm{F}=1: 2.1 \mathrm{con}$ tains higher amounts of free formaldehyde $(0.022 \%)$ than that of the molar ratio 1:1.4 $(0.011 \%)$. The higher amount of free formaldehyde in the resin of U:F 1:2.1 may explain its higher affinity towards ammonia and consequently the higher ammonia uptake and respectively the increase in the nitrogen content.

Open Access This article is distributed under the terms of the Creative Commons Attribution Noncommercial License which permits any noncommercial use, distribution, and reproduction in any medium, provided the original author(s) and source are credited.

\section{References}

Roffael E (1993) Formaldehyde release from particleboard and other wood-based panels. Malayan forest records, No 37

Westling A (1983) Ein neues Verfahren zur Verminderung der Formaldehydabgabe von Holzspanplatten und anderen Holzwerkstoffen. Holz-Zentbl 109:1802-1803 und 1806 